\title{
The Political Economy of Inclusive Growth
}

\author{
Mushtaq H. Khan ${ }^{1}$
}

Abstract: Growth is inclusive if it supports high levels of employment and rising wages. For developing countries, this means acquiring competitiveness in new sectors and technologies. Policies to support inclusive growth have to address significant market failures and have a mixed record across countries. Part of the difficulty lies in the 'political settlement' or social order in which policies and institutions are embedded. The political settlement is structurally different in developing countries compared to advanced ones, and across developing countries. Ambitious good governance strategies that aim to achieve strong enforcement of property rights across the board are unlikely to succeed in developing countries. The thrust of reform strategies has to shift towards building pragmatic 'developmental' governance capabilities that can enable the implementation of policies that target specific market failures in specific political settlements. The general argument is illustrated with reference to the recent experiences of Thailand.

(in de Mello, Luiz and Mark A. Dutz (eds) Promoting Inclusive Growth: Challenges and Policies, Paris: OECD Publishing 2012. pp. 15-54)

Also Available HTTP: http://www.oecd-ilibrary.org/economics/promoting-inclusivegrowth/the-political-economy-of-inclusive-growth_9789264168305-3en;jsessionid $=4 \mathrm{rg} 80 \mathrm{c} 1 \mathrm{r} 7 \mathrm{eqch} . \mathrm{delta}$

1 Professor of Economics, SOAS, University of London, e-mail: mk100@soas.ac.uk, http://www.soas.ac.uk/staff/staff31246.php 


\section{Introduction}

Inclusive growth is defined here as growth that is both sustainable and broad-based in terms of employment opportunities. Sustaining growth, particularly in developing countries, requires institutional solutions to address market failures. If the relevant market failures are primarily the result of weak property rights, the solution would be to focus on governance reforms that strengthen property rights. This is essentially the approach of 'good governance' reforms, with their emphasis on property right enforcement, rule of law, anti-corruption and political accountability. While many of these reforms are desirable in their own right, they are inadequate for addressing important market failures and in any case are difficult to implement. This is because the nature of the 'political settlement' in developing countries makes them structurally different from most advanced countries (though aspects of these problems can affect advanced countries too). Sustaining growth therefore requires specific institutional solutions to important market failures that can be implemented in particular political settlements.

This brings us back to the problem of governance, but in a different way. Implementing solutions to market failures requires governance capabilities that are different from and more specific compared with the capabilities required to enforce general good governance requirements. We highlight these differences by referring to 'governance for growth' or developmental governance as a strategy for developing the governance capabilities that are necessary to address market failures in specific political contexts. The question then is to identify policy and institutional instruments for addressing market failures that can be adequately enforced in a particular settlement, given existing enforcement capabilities or feasible improvements in enforcement capabilities through targeted 'developmental governance' reforms.

The significant differences in the performance of institutions across countries have been explained by difference in the social orders in which the institution is located (North, et al., 2007; North, et al., 2009). We analyse social orders using the analytical frame of 'political settlements' (Khan, 2010). A political settlement is a combination of institutions and organizations that can reproduce itself over time. Once a reproducible social order emerges, the relative power of different organizations is relatively stable and evolves along stable paths. This macro-level political economy can help to explain a fundamentally important observation: particular formal institutions appear to perform very differently across countries and over time. Our explanation focuses on the observation that if a particular institution implies a distribution of benefits that is out of line with the relative power of organizations sustained by the macro-political settlement, its implementation is likely to be resisted or altered by informal arrangements. Informal adjustments to formal institutions or their partial enforcement can therefore help to explain differences in the effectiveness of institutions and their success in achieving inclusive growth.

The paper is structured as follows: section 2 provides definitions and identifies the challenges of sustaining inclusive growth; section 3 summarizes the limitations of the 'good governance' agenda and the importance of focusing on a more limited range of 'developmental governance' capabilities; and section 4 describes our framework of political settlements as a tool for understanding the efficacy of different policy 
responses. We use the example of Thailand since the 1980s to illustrate how changes in the political settlement affected the choice and viability of growth strategies.

\section{Markets, institutions and inclusive growth}

The most important policies sustaining growth in the post-war period were identified in the Growth Report of the Commission on Growth and Development (2008). A first group of policies was important for supporting high levels of accumulation. A second group promoted innovation and technical imitation. A third group of policies achieved macro-economic stabilization. A fourth ensured the effective allocation of land, labour and capital. And finally there were policies that ensured social inclusion both for achieving developmental goals and for maintaining political stability (Commission on Growth and Development, 2008: 34). Countries used different policies and instruments to achieve these goals, and all countries did not perform equally strongly on all these fronts all the time. Nevertheless, sustained growth required policies that achieved a level of success on all these fronts. Macro-economic management has a separate literature and will not be examined further here. However, aspects of investment, technology acquisition, factor allocation and political stabilization are strongly interconnected with each other and with institutional and political governance capabilities. The governance capabilities that support policies in these areas are critical for sustaining inclusive growth.

The ability to compete in global markets has rightly been identified as an essential condition for sustaining growth. However, significant market failures can prevent developing countries from achieving or sustaining competitiveness. Market access is therefore necessary but not sufficient for sustaining inclusive growth. Low wages too are not sufficient to ensure inward capital flows or domestic investments. Indeed, in the presence of market failures, free markets can lead to divergence rather than convergence, as happened in many developing countries under colonial rule. For instance, from 1873 to 1947 Indian per capita income declined from around 25\% of US per capita income to under 10\% of the US level (Clark and Wolcott, 2002) during a period of close to zero tariffs, strong protection of the rights of British investors and virtually no restrictions on the repatriation of capital and profit. The proximate cause of this decline was simply that it was not profitable to invest in modern manufacturing or agriculture. The productivity of Indian workers was so low that even the low wages compared to those in the home country did not give India a competitive advantage for prospective British investors in most industries. This problem remains today for most sectors in most developing countries.

This appears to be a puzzle. Low productivity in poor countries should have been countered by private investments in up-skilling and training. Given the large wage differentials, small improvements in productivity would be sufficient to achieve competitiveness with more advanced countries. Private investments should have financed the acquisition of the requisite capabilities, particularly since what is missing is often not formal skills and education appropriate for the production process but the absence of know-how. Surely private investors should have been able to finance learning-by-doing in the workplace. The puzzle of low investments disappears when we look for significant market failures that may prevent investments, particularly in financing learning-by-doing. Without strategies to overcome these market failures, the only areas that are likely to grow in a poor economy are sectors that have already 
achieved international competitiveness. These are typically low technology and low value adding sectors with simple organizations where the productivity gap with more advanced competitors is likely to be low and the wage differential can compensate, giving the country a competitive advantage.

The challenge of sustaining inclusive growth in developing countries is that there are relatively few sectors that have already achieved international competitiveness or have prospects of achieving competitiveness rapidly. The rapid growth and employment generation that some developing countries have experienced in recent years can be traced to their achievement of global competitiveness in a few sectors, such as garments and textiles, cut flowers, toy and shoe manufacturing or food processing and packaging. A few developing countries like India have achieved global competitiveness in a small number of higher technology sectors, for example in software, pharmaceuticals, iron and steel, and automobiles. Middle-income countries face more serious problems particularly if, as is the case in Thailand, they rely on multinationals in sectors like automobiles and electronics. Moving into higher points on these value chains can require the development of domestic technological and entrepreneurial capabilities. In all these cases, success can be traced to specific processes of financing learning-by-doing and overcoming critical market failures (Khan, 2009b). The challenge of extending these successes to other sectors remains even in the most successful developing countries.

Achieving competitiveness involves much more than putting together machines and workers with the appropriate formal skills. Owners, managers and workers somehow have to acquire the know-how to operate new types of organizations and technologies. Without this know-how, investments in machines can fail and workers with formal education are likely to remain unemployed. Indeed, poor countries typically suffer from capital flight and the out-migration of skilled workers. The know-how involved in setting up factories, organizing production lines, managing quality control and order flows, maintaining work flows and so on is mostly 'tacit knowledge' that cannot be learnt in books and manuals. It can only be acquired through learning-by-doing with high levels of effort over time (Nelson and Winter, 1982; Stiglitz, 1987; Lall, 1992; Lall and Teubal, 1998; Lall, 2000a, 2000b).

Sustaining inclusive growth can therefore be interpreted as a process of opening up new sectors and moving existing sectors up the quality and value chain. Investment in productive capacity and formal education are necessary but not sufficient for this, particularly in developing countries. At least as important are the investments in financing loss-making periods of learning during which organizational and technological capabilities are acquired. However, financiers will only be interested in this if they can be sure that they will not lose out because of poor levels of effort by those being financed. Outside financiers may not be able to satisfactorily contract for or enforce these conditions, particularly in developing countries, and as a result they avoid these areas. Policy can address these market failures by reducing the cost or risk of financing loss-making learning periods, provided the governance capabilities are in place to ensure that the opportunities created are not wasted in their turn (Khan, $2000 \mathrm{~b}, 2009 \mathrm{~b}$ ). In the literature on technology acquisition, it is recognized that responding to these market failures involves the creation and management of new opportunities in some sectors. These opportunities can be described as rents and have variously been referred to as learning rents (Khan, 2000b), contingent rents (Aoki, et 
al., 1997: 14-18) or performance-indexed rewards (World Bank, 1993). To achieve the learning objective, rents have to be conditional, and agencies managing these rents have to have the critical capability to withdraw or re-allocate rents if performance is poor.

A further set of significant market failures affect land markets and can set important constraints, particularly in developing countries. Investors often find it impossible to buy land for expanding or setting up plant. This is because of structurally high transaction costs in land markets, which can be traced to poorly defined land rights, multiple claims on land, poor contracting institutions and often very fragmented land ownership. These are general problems that can become a serious constraint in densely populated countries like India. The net effect is that the cost of acquiring land becomes so high that potential investors are put off from investing, particularly in regions that are most in need of employment generation. Establishing well-defined property rights to reduce these transaction costs is unrealistic in the medium term for reasons that we will discuss. As a result, investors in developing countries regularly invoke non-market processes to acquire land. This can range from state purchase orders to acquire land for industrial development, the allocation of public land to industrial zones, and the involvement of political actors or even mafias in land acquisition. The allocation of land using non-market or part-market processes can imply significant rents for the beneficiaries. The conditions of allocating these rents once again describe the difference between rewarding unproductive clients, speculation and accelerated industrialization. Here too, the governance capabilities of specific agencies can explain significant differences in performance across countries.

Governance capabilities for enforcing institutions, rents and market failures refer to closely connected concepts. Institutions are rules that describe how social actors act (North, 1990). Property rights that define who can do what with an asset are institutions, and so are rules of taxation, subsidization or conditional financing. The economic effect of an institution depends not only on what the rules specify but also on the degree to which they are followed or enforced. Institutions are formal if they are enforced by the state, and informal if they are self-enforced or enforced partly or entirely by non-state actors or agencies. Organizations are the agencies that operate under these institutional rules. Political organizations organize their members and broader constituencies to achieve political goals. Typically they seek to change institutional rules in ways that favour particular constituencies. Economic organizations are engaged in organizing production. The governance capabilities to which we are referring are state capabilities for enforcing formal institutions. If all necessary property rights could be enforced by the state at reasonably low cost, we would have an ideal market economy based on voluntary contracting between organizations. Under these conditions, organizations should be able to achieve all or almost all socially beneficial arrangements through voluntary contracting: in other words, there would be few market failures. Enforcing formal institutions like property rights and the rule of law is therefore a critical requirement of market-enhancing governance. However, enforcing formal institutions is expensive. It is difficult to sustain spending on protecting property rights that is out of line with what asset owners can collectively afford, given the average productivity of assets. It is not surprising that poorer countries tend to score systematically lower on property rights, rule of law and other 'good governance' scores compared with more advanced countries. 
Rents are incremental incomes that are typically associated with specific institutions. If markets were ideal and property rights were perfectly enforced, the emergence of rents would very likely signal value-reducing institutional changes, such as barriers to entry creating monopoly rents. However, in a world with significant market failures, rents may be associated with institutional changes that enhance welfare. Examples include efficiency wages or subsidies to firms to reduce their carbon emissions. Rents can also be redistributive for the purposes of achieving political stability. Sometimes rents can bring about political stability in ways that allow other rents to be managed to solve market failures. But at other times, redistributive coalitions can affect the management of all rents, including those potentially necessary for growth, with very damaging consequences. The presence of rents in an economy therefore does not tell us much about the implications for efficiency and growth-that requires an analysis of the specific types of rents that are present and the conditions of their creation and allocation (Khan, 2000a, 2000b). The challenge is clearly that states require a minimal set of 'developmental' governance capabilities to ensure that important growth strategies and their associated rents can be effectively managed.

Most examples of market failures illustrate that when societies respond to these market failures, rents are inevitably created. However, if policy results in the emergence of policy-induced rents, then this is likely to induce rent seeking. Rent seeking is the expenditure of resources by organizations that seek to change the structure, types and allocations of rents. Not only does rent seeking imply a resource cost since resources are used up in these activities, but it can also subvert the formulation and implementation of policies in ways that prevent the resolution of the market failure (Khan, 2000b, 2007a). Thus, another way of thinking about developmental governance is that it is about strengthening the governance capabilities that support specific policies so that the latter is not subverted by rent seeking. Rent seeking can be damaging either because it distorts policy ex ante so that in the name of correcting market failures rents are created for unproductive rent seekers, or because it can subvert policy ex post by allowing rents to be captured by firms or individuals without solving the market failure. In a world full of rents, however, rent seeking cannot be reduced to zero. Rather, in the context of particular policies, the aim should be to ensure that the resource cost of rent seeking and any distortion in policy is not so great that the net effect of the policy becomes negative. The lower the cost of the rent seeking and the lower the policy distortion for useful rents, the betterbut aiming for zero rent seeking is equivalent to aiming for zero carbon emissions to save the environment (Khan, 2000a). The social optimum here too is to maximize the net benefit.

\section{Governance and growth}

There have been two broad types of policy responses to the market failures that constrain growth in poor countries. Before the 1980s, it was common to use broadbased interventions like tariffs and subsidies (that created extensive rents) to accelerate learning and technology acquisition. Very often these strategies had disappointing results because the range of market failures, which policy-makers tried to address, were too broadly defined and, in most cases, the governance capabilities of the state were not remotely sufficient to enforce the requirements for success. Rents associated with potentially beneficial interventions failed because powerful groups 
could focus on capturing the rents without delivering the desired results. In the worst cases, infant industries refused to grow up, subsidies proliferated and became a way of life, and public sector enterprises made persistent losses.

In contrast, the dramatic success of a small number of East Asian countries in the 1960s and beyond was based on their ability to manage policy-induced rents so that they served as incentives and opportunities for achieving new capabilities, rather than as unconditional gifts that could be captured by the powerful (World Bank, 1993). A comparison of the performance of the East Asian countries with the others should have led to the reasonable conclusion that the others did not have the same capability to manage the rents their policies had created. An appropriate response would have been to scale down the range of interventions in less successful countries in order to target the most critical market failures, and improve developmental governance capabilities in vital policy areas. Instead, the response from the late 1970s onwards was towards liberalization and 'good governance' strategies that were actually even more ambitious. These sought to address market failures by making markets more efficient across the board. The strategy was to enhance a number of marketenhancing governance capabilities for enforcing property rights and a rule of law, and reducing corruption, which could in theory reduce market transaction costs and allow private contracting to proceed more efficiently (Khan, 2007b, 2008a).

The limitations of an exclusive focus on market-enhancing strategies like 'good governance' are well known (Khan, 2008a). If significant reductions in transaction costs could be achieved in this way, the market failures that prevent investment in new sectors may disappear. However, while many of the good governance reforms are desirable in themselves, they are unlikely to be implemented to a significant degree in the near future for structural reasons that are primarily to do with the political settlements of developing countries, rather than a weakness of 'political will' (Khan, 2007a). It is not surprising that an empirical relationship between a policy commitment to market-enhancing governance and accelerated economic growth has not been established. A weak positive relationship has been identified in many regression exercises between actual improvements in 'good governance' indicators and economic growth, but the strength of the relationship is weak and the regression analysis shows that the additional growth, which achievable improvements in good governance can offer, is limited (Kurtz and Schrank, 2007). Deriving important policy conclusions from the results of weak multi-country regression results is problematic. For one thing, given the two-way causality that everyone accepts between good governance scores and economic growth, it is difficult to identify the true strength of the relationship in one direction using available econometric techniques.

Another problem is that the data to test these theories is weak and available only from the 1990s (Arndt and Oman, 2006). Given the limited support from cross-section data, supporters of good governance policies (for instance, Kaufmann, et al., 2007) have sought support in long-run econometric exercises using instrumental variables, such as in the work of Acemoglu, Johnson and Robinson (2001, 2002). Here instrumental variables that explain where settler colonialism was established are found to correlate with high per capita incomes today. The authors claim that this is because settler colonialism established stable property rights. However, the econometrics only establishes that settler colonies did better; it does not establish that they did better because they first established stable property rights. Other factors were also correlated 
with the onset of settler colonialism, for instance, the entry of settlers with higher human capital (Glaeser, et al., 2004). More significantly for the claims of good governance theory, the period of economic transformation in settler colonies was historically one of violent property right disruptions (Khan, 2009a). These transformations involved significant transfers of assets from indigenous populations to settlers. But settler colonialism did not first establish property rights that then allowed efficient markets to transfer assets from indigenous populations to more efficient users; rather, settler colonies used 'institutions' of violence to destroy preexisting rights by force. Paradoxically, these forced transfers allowed them to carry out rapid transformations in the organization of production, which achieved the growth in productivity that subsequently allowed property rights to be adequately protected, but the process of transformation that is primarily of interest to developing countries was neither based on stable property rights nor did it attempt to minimize social costs.

Nobody can dispute the long-run relationship between social productivity and stable property rights. As assets become more productive, they can begin to pay for their effective protection and property rights are likely to be better protected. Nor can it be disputed that everything else being the same, if property rights are better defined, there will be positive effects on time horizons, transaction costs and investments. The question is really about feasible governance priorities during the period of transformation when asset use and social organization are rapidly changing from traditional to formal productive structures. Far from establishing that good governance is a pre-condition for these transformations, settler colonialism, with its extreme disregard for the rights of indigenous populations, provides an entirely inappropriate model of how to achieve developmental transformations. Thus, neither the cross-section nor the instrumental variable regressions provide convincing evidence that countries can make a significant transition from poverty to prosperity by first achieving good governance capabilities. We can accept that improvements in good governance capabilities could result in some improvements in development performance, but we have no evidence that achievable improvements along these dimensions are sufficient for developmental transformations.

The role of policy and of rents in accelerating these transitions has to be understood in this context. Since forced transitions are neither feasible nor desirable, the role of policy must be to create incentives and compulsions to move society in productive directions within the limits set by their inherited political settlements. Unfortunately, the discussion about developmental governance was for a time dominated by the experiences of the East Asian tigers in the 1960s and 1970s (for instance, Amsden, 1989; Wade, 1990). This was unfortunate because these countries had exceptional political and institutional capabilities to manage an extensive range of developmental rents while most countries do not. So if addressing market failures required East Asian capabilities, then aiming for developmental governance would be inappropriate for most countries. East Asian capabilities were, however, not based on an ability to 'pick winners'. The latter implies a degree of prescience that neither private investors nor bureaucrats can be expected to have. Rather their success was based on supporting investment in areas where new productive capabilities could be developed and withdrawing conditional rents if competitiveness failed to emerge in time. 
Other countries with ambitious rent strategies performed less well because they lacked the governance capability to discipline and manage their developmental rents. In less dynamic countries, firms and sectors that did not engage in learning or technology acquisition could retain their rents by using political influence. In this way, potentially productive rents effectively became redistributive rents. As political stability is important for all countries, an important policy message is that the redistributive rents required for stability have to be separated from developmental rents, which need to be managed and allocated differently. Clearly, most countries could not hope to manage developmental rents on the East Asian scale, but it was equally futile for them to hope that they could achieve significant good governance capabilities in economies that were still largely pre-capitalist. Achievable improvements in good governance could enable some improvements in market efficiency but this was unlikely to be sufficient for enabling the huge structural changes required for economic transformation solely on the basis of voluntary market contracts. The realistic if difficult strategy must be to develop a limited range of developmental governance capabilities in each country, taking into account both the significant market failures that they face and the specific constraints on policy implementation and institutional enforcement determined by their political settlements.

\section{Political settlements and the enforcement of institutions}

There is a growing recognition that the macro-political economy defined by the 'social order' of a country matters for the operation of its institutions (North, et al., 2007; North, et al., 2009). In our model of a social order (based on the analysis of political settlements), the relative power of organizations plays an important role in explaining the enforcement of particular institutions (Khan, 2010). The relative power of organizations of different types matters because the ability of different groups to contest, obstruct or oppose rules that they perceive to be against their interests clearly affects their enforceability. Thus, formal property rights or strategies of financing learning-by-doing may fail either because they were inappropriately designed or because they could not be effectively enforced. Relative power can be ranked in terms of many dimensions. The dimension that is most useful for us is holding power. This refers to how long a particular organization can hold out in actual or potential conflicts against other organizations or the state. Holding power is a function of a number of different characteristics of an organization, including its economic ability to spend money to protect its interests, its ability to inflict costs on competing organizations, its ability to mobilize supporters to absorb costs during conflicts, and its ability to mobilize ideologies to consolidate and keep its members committed. As the outcomes of conflicts depend on relative rather than absolute power, our use of the word power refers to a distribution of power. Holding power is correlated to some extent with economic power, but it is also based on organizational capabilities. This is why holding power cannot be reduced to economic power, and richer individuals and organizations do not always win in conflicts.

The 'political settlement' describes the macro political economy of a social order. We define a political settlement as a reproducible combination of organizations (with a defined distribution of power) and an institutional structure (Khan, 2010). To be sustainable, the distribution of power across organizations has to allow the enforcement of a combination of formal and informal rules that is sufficient for the 
political and economic viability of the society. Economic viability or reproduction is a level of economic activity that avoids a crisis. The minimum level of economic performance depends on the expectations of its organization and can vary across societies. Political viability requires that the core institutional and political arrangements that define the political settlement do not begin to unravel because of conflict and violence. A political settlement's degree of robustness depends on how the economy and polity are operating with respect to these minimum viability limits. However, the minimum levels of economic and political viability are not defined in absolute terms but are themselves endogenous to the society.

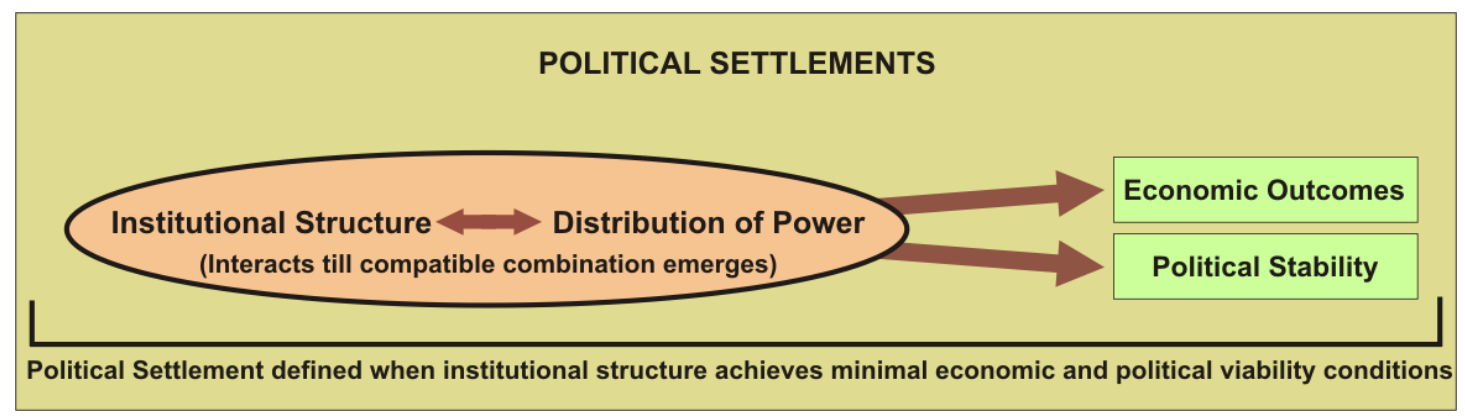

Figure 1: Political Settlements

Source: Khan (2010)

There are two levels at which the interactions of institutions and the distribution of power are analytically significant. The first is a macro level of interaction, which operates at the level of a society as a whole to define the political settlement. Figure 1 describes this interaction between institutions (both formal and informal) that collectively constitute the institutional structure and the distribution of power across organizations in that society. A system of institutions and a distribution of power across organizations is a political settlement if the resultant economic outcomes and levels of political stability are sustainable. Institutions and the distribution of power are necessarily an interdependent system. First, institutions affect the distribution of power because they sustain a distribution of economic benefits across organizations that contribute to their relative holding power. Secondly, the distribution of power across organizations affects institutions because powerful organizations are likely to determine the evolution and enforcement of formal and informal institutions to achieve the distributions of benefits that they desire. Both are likely to interact until a sustainable combination of institutions and a distribution of power emerges. Once this happens, both the institutions and the distribution of power are mutually supportive. A political settlement therefore sustains a distribution of power. This brings us to the second or micro-level of interaction, which is particularly relevant for policy assessments of the feasibility of different directions of incremental institutional change. The distribution of power, which is supported by the current political settlement, is relevant for understanding the resistance to the introduction and proper management of particular institutions since every incremental institutional change also changes the distribution of benefits in society and this will be supported or resisted by different organizations.

The political settlement in developing countries is of particular interest because these countries are by definition going through transition and transformation. This transformation (along very different trajectories and rates across countries) involves 
production shifting from traditional, pre-capitalist organizations to modern organizations, using more sophisticated technologies and requiring complex organizational structures and new social hierarchies. While this transformation is taking place, the pre-existing distribution of power between individuals and organizations does not disappear immediately, but rather new formal institutions and new types of organizations emerge and coexist. The result is that formal institutions are set up during this period appropriate for the needs of modern organizations and typically based on institutions and organizations in more advanced societies. In theory, these formal rules support a distribution of benefits at the micro-level that is consistent with the property rights and hierarchies of modern organizations but this distribution may be difficult to enforce given that the actual distribution of holding power between organizations is likely to be significantly different at the macro-level. The lack of 'alignment' between prior distributions of power and the distribution of benefits that would emerge if the formal rights supporting the future productive economy could be fully enforced lies at the heart of the social order problem in developing countries.

This is why informal institutions play a much more important role in developing countries than they do in advanced ones. Informal institutions are rules that are not enforced by formal agencies. They include behaviour that is supported by habits, customs, cultures and values; however, they also include rules that may appear to be formal but are actually enforced by informal agencies like mafias and patron-client organizations. Various reasons have been offered to explain the dominance of informal institutions in developing countries, including the weakness of state capabilities in enforcing formal institutions. If the weakness of enforcement capacities were the primary reason for poor enforcement, the 'good governance' reform agenda implemented with some external assistance would have helped, but developing countries have remained decidedly 'non-Weberian' regardless of attempts at strengthening formal enforcement. This can be understood if we recognize that the full enforcement of formal institutions in these contexts is very strongly resisted given the actual distribution of power at the macro-level of the political settlement. Only when the vast majority of organizations have become formal productive ones is the distribution of organizational power likely to support the full enforcement of formal rules. Developing countries can therefore be described as having variants of clientelist political settlements. Here informal institutions and arrangements, in particular operating through clientelism, play an important role in adjusting the distribution of benefits to sustain the interests and power of powerful organizations that operate outside the formal sector. The variations within the broadly defined clientelist political settlement across developing countries are, however, even more important because they define the limits of different strategies for sustaining growth.

These variations are important for our second level of analysis, shown in Figure 2. This looks at the economic implications of attempting to introduce new 'incremental' institutions within a specific political settlement. Standard institutional analysis typically looks at particular institutions in isolation. This theoretical analysis of incentives and outcomes is shown in the left-hand half of Figure 2. At best, it is recognized that the norms and values of the host population may affect the costs of enforcement. Unless values and cultural norms are exogenous and not amenable to change in response to economic opportunities, they can at best explain small and relatively transient differences in institutional outcomes. In contrast, by locating the 
analysis of institutions (and economic policies more generally) within a macroanalysis of political settlements, we can explain differences in the enforceability of particular institutions in different contexts.

Any particular (incremental) formal institution that is the subject of policy implies specific distributive outcomes that may or may not be consistent with the macrodistribution of organizational power that is described by the political settlement. An analysis of the links in the right-hand half of Figure 2 has a number of important implications. First, if the enforcement of formal institutions is constrained by the distribution of organizational power, which is sustained by the 'social order', we can begin to explain why the performance of institutions and policies has varied so greatly across countries. In particular, institutions and policies that are the most developmental can vary significantly across countries. What may be theoretically a 'second-best' institution may actually be 'first-best' once we account for differences in resistance and enforcement costs that may result in a worse outcome with the theoretically best institutional strategy.

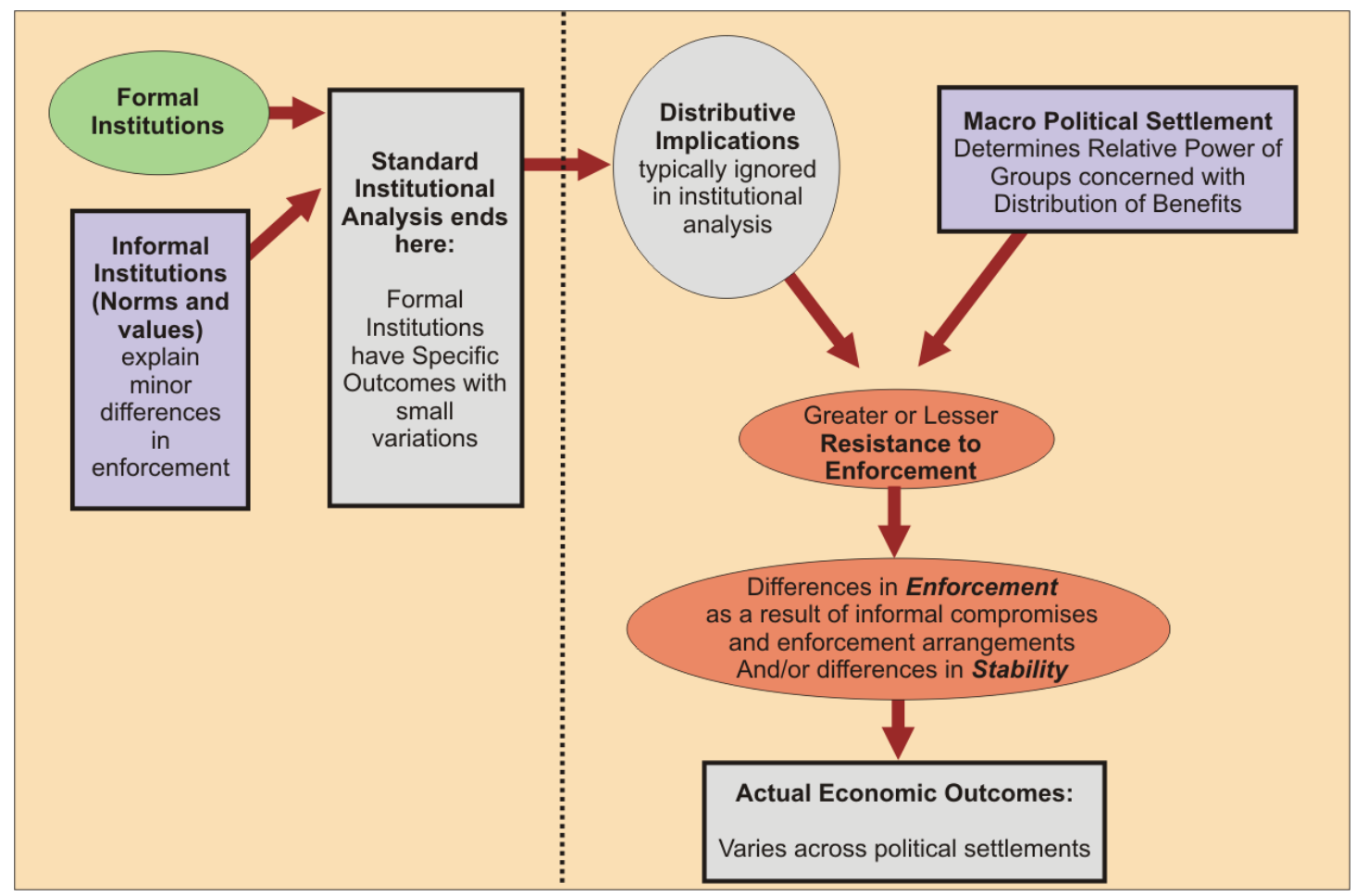

Figure 2: Political Settlements, Partial Enforcement and Institutional Performance

Source: Author

Secondly, the political settlement in most developing countries also explains why ambitious developmental strategies of the East Asian type have generally failed. The East Asian states had very specific political settlements with weak political organizations (whether formal or informal), which was a product of Japanese strategies of colonial rule. In contrast, in the more typical British and French colonial strategies, indigenous elites were used in the colonial administration, together with strategies of divide and rule. Political organizations therefore evolved to be much stronger (Khan, 1999, 2000a). Thirdly, the characteristics of the political settlement in developing countries can explain why, in general, good governance strategies have 
fared so poorly. If the social order in developing countries has to be systematically responsive to organizations with power outside the formal economy, the enforcement of formal institutions is unlikely to be very good. In particular, the distribution of benefits to politically important, informal organizations is likely to involve informal institutions and informally managed rents. Finally, in some countries, the political settlement may be so adverse that the space for feasible reforms may be very limited. There may be no feasible improvements in governance capabilities that would allow even a few important market failures to be adequately addressed. Here an understanding of political settlements and the experiences of other countries may suggest strategies of political reorganization to change the political settlement itselfbut the difficulty and hazards of such strategies need not be stressed.

There are many dimensions of the distribution of power between organizations in a macro-political settlement that could potentially affect the performance of particular institutions and policies. To make the analysis tractable, we focus on a few dimensions that are likely to have more significant effects on institutional enforcement and performance. Two dimensions appear to be particularly important (Khan, 2010). The first is the distribution of power between political organizations, which can be analysed by looking at the construction of the ruling coalition. This has important implications for the enforceability of different types of interventions and institutions. A second dimension is the distribution of power between economic and political organizations. The productive capabilities of capitalist organizations and the strength of their linkages with political organizations define this dimension of the political settlement, which also affects the enforceability of different types of institutions (Khan, 2010). In this paper I focus on the first dimension-the relative power of political organizations-to illustrate the implications for institutions and governance.

Political organizations in developing countries are typically based on patron-client relationships. Bigger political organizations are coalitions of smaller ones. Smaller organizations join bigger coalitions at different levels of the pyramid, depending on the organizational power that they bring to the coalition and the strategies of inclusion of the coalition leadership. The pyramid that constitutes the ruling coalition is distinguished both by the number and strength of the coalitions it includes and excludes, and the power of higher-level organizations (ultimately the coalition leadership) vis-à-vis lower-level organizations within the ruling coalition. These organizational differences in the construction of the ruling coalition can often have significant implications for the enforcement and operation of institutions. 


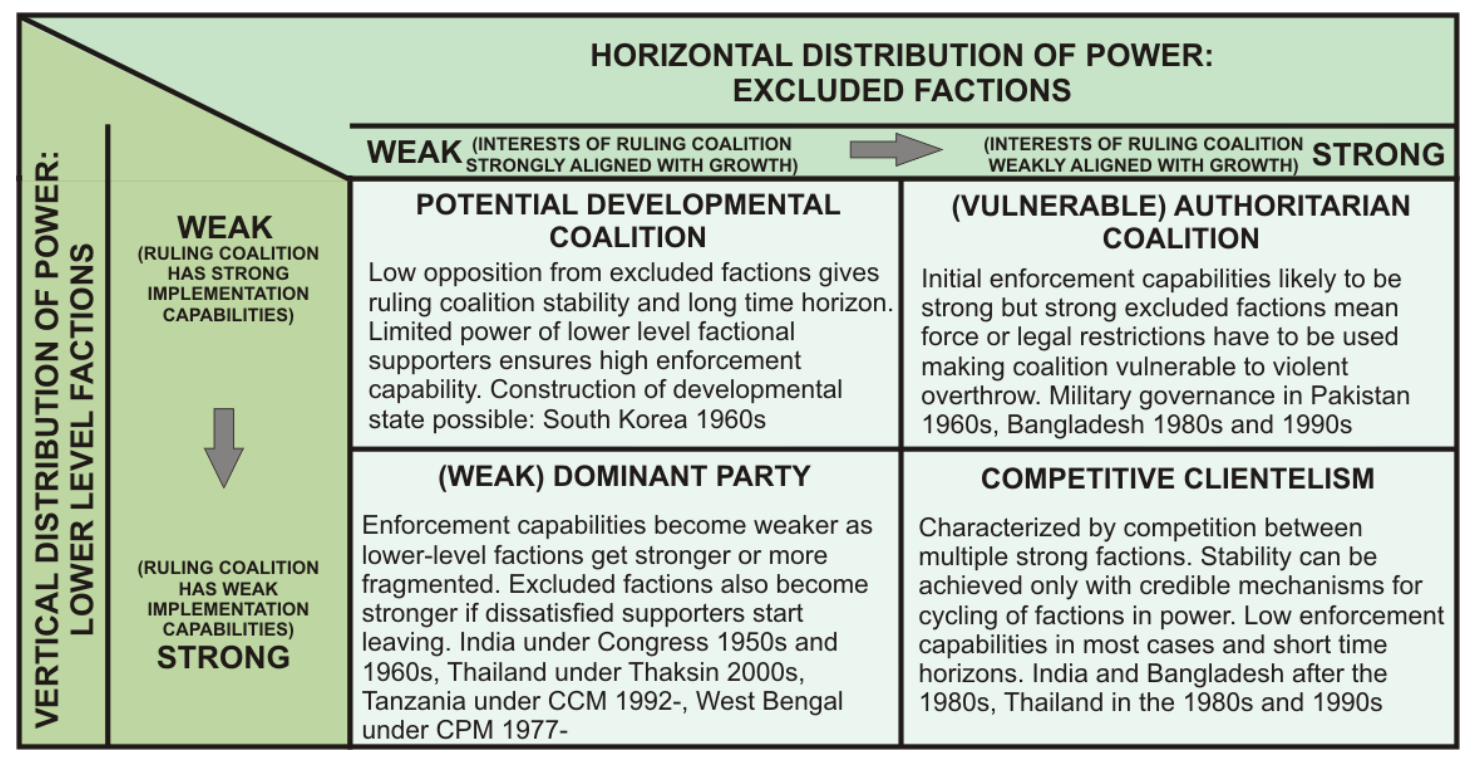

Figure 3: The Ruling Coalition in Clientelist Political Settlements

Source: (Khan, 2010)

Figure 3 shows these two dimensions of interest in the construction of the ruling coalition. The first is the 'horizontal distribution of power'. This describes the power of excluded political organizations relative to the ruling coalition. If excluded coalitions are weak, the ruling coalition is likely to feel secure and act with a longer time horizon. Excluded political organizations can range from very weak to almost as powerful as the ruling coalition. At its limit, if excluded coalitions become more powerful than the ruling coalition, the latter is unlikely to survive. The relative strength of excluded organizations can be assessed by looking at their organization and strategies, the success with which they engage in conflicts, and the informal and formal distributions of benefits that they are able to achieve. Excluded coalitions can be weak for different reasons. The most benign possibility is that all, or almost all, powerful political organizations have been incorporated within the ruling coalition. It could also be that the distribution of power across factions was skewed to begin with, and factions within the ruling coalition happen to be significantly more powerful than excluded factions, even if the latter are numerous. However, if there are administrative, legal or military restrictions on excluded groups, it can be difficult to assess whether they are actually weak or simply quiescent in the face of obstacles. The more extensive the obstacles to the organization of excluded groups, the more likely it is that they are actually strong and have to be repressed to be excluded. However, exclusion based on repression is not likely to be sustainable over long periods of time.

The second dimension describing the ruling coalition is the 'vertical distribution of power'. This refers to the relative power of higher compared to lower-level organizations within the ruling coalition. By definition, lower levels in a patron-client hierarchy are always weaker and to some extent dependent on higher levels. However, this too can vary from a situation where lower-level organizations have little bargaining power to one where they can effectively block or limit the implementation of policies that are supported by higher levels if their demands are not met. When lower-level organizations have little holding power, higher levels can select or abandon lower-level client organizations without facing great resistance. This makes 
it easier to ensure that lower levels implement the policies that are adopted by higher levels. In contrast, when lower-level organizations have significant holding power, they can impose serious costs on their patrons if they are not satisfied. This in turn can mean that the enforcement of particular rules becomes more difficult for two reasons. First, collective action within the ruling coalition to agree about the rules to be enforced is now more difficult, as lower-level organizations that do not agree with particular rules can veto the agreement more easily. Second, organizations outside the ruling coalition may find it easier to block the enforcement of rules that are against their interests because it becomes easier to find powerful lower-level organizations within the ruling coalition that will go against their leadership for a price and block the implementation of particular rules.

These two dimensions range along a continuous scale defining four limiting types of ruling coalition in Figure 3. At the top left-hand corner is a ruling coalition, which we describe as a potential developmental coalition. Here the ruling coalition faces little contestation from horizontally excluded groups. This gives it the confidence to have a long time horizon and aligns its interests with long-term development. In addition, the superior power of higher-level organizations means that the ruling coalition has effective implementation capabilities. These features imply that this is potentially the most developmental coalition, provided that there are pressures on the leadership to be developmental, as well as minimal technological capabilities within the economic organizations to benefit from growth-supporting policies. Solutions to market failures are more likely to be selected and enforced under such a ruling coalition. The ruling coalition in South Korea or Taiwan from the 1960s to the 1980s approximated these developmental characteristics. Ambitious and broad-based developmental rents could be effectively managed to drive sustained and inclusive growth. Other conditions of course are also important, such as the internal and external pressures to adopt inclusive growth strategies, which depend on the organization of interests within society and its relationship with external forces; however, without a political settlement that provides adequate time horizons and implementation capabilities on the part of the ruling coalition, the demand for generating growth is likely to remain unrealized. The important point is that this aspect of the distribution of power across political organizations in East Asia was not at all typical and this is why it did not provide a replicable model for other countries. Most other countries inherited a more 'adverse' distribution of power across political organizations from their colonial histories, giving their ruling coalition poorer time horizons or implementation capabilities.

A second type of ruling coalition is shown in the top right-hand corner, which we describe as an authoritarian coalition. In this configuration, excluded organizations are strong and the ruling coalition has to survive by limiting the capabilities of the excluded in some way. Thus formal or informal arrangements are likely to be used to restrict political activity outside the ruling coalition. Authoritarianism is difficult to sustain for long unless there are special factors, such as natural resource rents or military support that bolsters the exclusion capabilities of the ruling coalition. Nevertheless, the fact that excluded coalitions are actually strong is likely to result in periodic demonstrations of strength by the excluded. Developmental coalitions can also impose administrative restrictions on excluded organizations, like the martial law restrictions in Taiwan from the 1950s, but in such cases excluded coalitions are actually weak so, for instance, there was no significant resistance in Taiwan over 
several decades. Thus, if excluded organizations are powerful, it is likely that there are restrictions on their organizational freedom, but the presence of restrictions does not necessarily mean that they are powerful. The second characteristic of the authoritarian coalition is that lower-level organizations are relatively weak, which gives higher levels relatively high implementation capabilities. If lower-level organizations were strong, the authoritarian coalition would become unsustainable because in that configuration it would be difficult to satisfy lower-level organizations and there would be powerful tendencies for lower-level organizations to defect to one of the excluded coalitions for a better deal. As already strong excluded coalitions get stronger, the ruling coalition becomes more vulnerable and is eventually likely to become unviable.

Conversely, the presence of strong external organizations in this configuration is likely to increase the bargaining power of lower-level organizations as they can threaten to leave and join an excluded organization. If the leadership is unwilling or unable to pay more, some do leave, further strengthening excluded coalitions and increasing the bargaining power of remaining lower-level organizations. This type of cumulative breakdown can rapidly undermine authoritarian coalitions. As defections increase the power of the excluded, violence is more likely to become the ultimate exclusion strategy of the authoritarian coalition. However, if violence has to be actually implemented on a sustained basis, the ruling coalition is unlikely to remain viable and can suddenly collapse, as happened in several North African and Middle Eastern countries in 2011. Authoritarian coalitions facing weaker excluded coalitions (those towards the centre of the horizontal range of variation in Figure 3) are less likely to have to use violence. For instance, Tanzania's one-party state under TANU in the 1960s faced very little resistance from excluded factions, even though organizational rights were limited in a pre-emptive way to prevent resistance developing. In contrast, the military-controlled ruling coalition in Pakistan/Bangladesh in the 1960s initially faced weak excluded coalitions, but had to resort to violence as excluded coalitions became stronger. It was eventually overthrown by a mass uprising in 1969. As with a developmental coalition, the enforcement capabilities of authoritarian coalitions are relatively good, but time horizons are likely to be poorer given the vulnerability of the leadership. Nonetheless, given the tendencies for lower-level factions to become stronger over time, the capacity to implement is likely to get progressively poorer. Authoritarianism is therefore likely to suffer progressively weaker implementation capabilities even if it began with stronger capabilities. Its time horizon is also likely to collapse further as excluded groups become stronger (Khan, 2010).

The third type of ruling coalition is the dominant party, which is 'dominant' to varying extents. In this case, excluded political organizations are weak. This is because either all or most of the powerful factions have been included within the dominant party, or else excluded factions are too fragmented to pose an effective threat. The characteristic feature that distinguishes the dominant party from authoritarian arrangements is that it does not have to use administrative or military power to the same extent to exclude others,, and indeed could win formal, contested elections. The dominant party therefore enjoys a longer time horizon. However, the inclusion of many political organizations within the ruling coalition creates numerous potential points at which implementation can be vetoed. Lower-level organizations tend to be relatively powerful as a result of greater inclusion and many internal 
coalitions have to be satisfied to achieve implementation. The implementation capabilities of this ruling coalition are therefore weaker when compared with developmental coalitions but often also relative to authoritarian coalitions, particularly those at an early stage of their life when their implementation capabilities can be quite strong. Like authoritarianism, the dominant party also faces a structural dilemma. If it includes all the powerful organizations within it, it can remove threats from outsidebut at a price. Rents will be spread more thinly and dissatisfaction is likely to result in blocked implementation. Sooner or later, dissatisfied internal organizations are likely to start joining excluded groups, and once this begins, the process of cumulative decline is difficult the stop. Dominant parties are likely to begin with long time horizons but constrained implementation capabilities; however, both are likely to decline over time, perhaps precipitously due to cumulative causation. India under the Congress Party in the 1950s and 1960s, Tanzania under the CCM, West Bengal under the CPM from 1977 to 2011, Thaksin's Thai Rak Thai in Thailand from 2001-2006 were variants of dominant party coalitions that enjoyed different levels of vulnerability and weakness.

This brings us to the fourth and final variant, which describes the default structure of clientelist political settlements when authoritarian and dominant party arrangements break down. This is competitive clientelism, where the number of clientelist political organizations is so great, or so fragmented, that the inclusion of all of them in a ruling coalition would not work, but neither would a strategy of keeping excluded groups out by legal or military mechanisms. The only sustainable (if vulnerable) arrangement is for alternative coalitions to cycle in and out of power in a reasonably orderly way. Democracy in developing countries is typically based on variants of competitive clientelism rather than a rule-following competition for power between parties with different manifestos for taxing and spending. In competitive clientelism, the ruling coalition is formed by political entrepreneurs, who seek to bring together enough political organizations within their coalition to be able to rule at the lowest price for themselves. The excluded are technically free to organize, restructure and entice factions that are currently included in the ruling coalition to leave and join them in an attempt to form a new coalition. Given the relative power of the excluded, the expectation is that coalitions will cycle in and out of power. Elections in this system provide a mechanism for testing the organizational power of competing coalitions, and elections are successful if they reflect the balance of organizational power on the ground. However, competitive clientelism is only sustainable if there is an 'implicit rule of law' amongst the competing coalitions that ensures that losers accept the outcomes of these contests without descending into open warfare. Competitive clientelism can provide comparative stability when the underlying factional structure is very fragmented because attempts to sustain authoritarian or dominant party coalitions in these contexts are likely to result in instability and violence. Thus, the equilibrium modes of developmental, authoritarian and dominant party coalitions are likely to have longer time horizons and better implementation capabilities than competitive clientelism, but if the underlying distribution of power between political organizations does not support these institutional arrangements, then the imposition of these forms can produce worse outcomes than the equilibrium mode of competitive clientelism. This is why attempts to sustain authoritarianism when the underlying distribution of power has changed can result in very poor economic outcomes, and a transition to competitive clientelism can (after a sustainable equilibrium has been achieved) provide relatively better results. 
Understanding competitive clientelism is important because it is the political settlement that underpins democracies in developing countries. For instance, as authoritarian arrangements collapse in the Middle East, the likely outcome is the eventual emergence of competitive clientelism rather than Weberian social democracies. It is important for policy-makers to understand the challenges for governance and institution-building in these contexts. The political configuration here faces challenges from a number of directions. First, political stability in this power arrangement requires that the ruling coalition understands the relative power of excluded groups and internalizes the futility of using administrative power as a longterm strategy of exclusion. Secondly, the design of governance institutions in this context has to take into account the specific problems of short-termism and generally weak implementation capacities. The imperative of focusing on developing targeted governance capabilities is most important in this context precisely because of the general characteristics of competitive clientelism. Attempts to develop broad-based 'good governance' capabilities are likely to fail in any variant of a clientelist political settlement, but it is particularly difficult in competitive clientelism with its short time horizons and weak implementation capabilities. This may appear paradoxical because this variant has features of political accountability that authoritarian or dominant party systems appear to lack. However, sustaining growth in any of these contexts requires the identification of critical areas of market failures that constrain growth and the development of targeted governance capabilities for addressing some of these problems to the greatest extent possible.

The conditions for sustaining stability are frequently violated in competitive clientelism because the ruling coalition has a temptation to believe that it can leverage administrative powers to keep the opposition permanently excluded. In other words, the ruling coalition can suffer from the misapprehension that it can be an authoritarian coalition. The real distribution of power between political organizations, however, precludes authoritarian solutions, and attempts in that direction only result in repeated crises of violence. Paradoxically this can create strong pressures for organizations, like the military, to attempt to re-create an authoritarian coalition that is based on stronger exclusion capabilities, or for the ruling coalition to attempt to construct a dominant party. But given the underlying distribution of power, these attempts are also likely to be short-lived unless there is a significant political project of social engineering to reconstruct political organizations-otherwise, the cycle of democratic interludes that end in electoral crises, followed by military takeovers and attempts at authoritarianism, is likely to continue. A sustainable competitive clientelism requires credible mechanisms that allow the ruling coalition to be replaced in elections by an alternative coalition if the latter acquires greater holding power. This cannot be guaranteed simply through formal electoral rules in societies where so much happens informally. What is required is that elite expectations have to adapt to recognize that the use of administrative power to exclude powerful coalitions cannot cross socially acceptable limits. This is difficult to achieve. As a result, democracy is not always a stabilizing force in developing countries, nor does it necessarily generate developmental outcomes if appropriate governance capabilities cannot be developed.

Today all of South Asia is governed by competitive clientelist coalitions as is much of Africa, though there are exceptions, such as Tanzania, which remains under a dominant party. Thailand in the 1980s and 1990s was also characterized by 
competitive clientelist coalitions until the emergence of a dominant party resulted in the military coup of 2006. Indeed only India has achieved an internal equilibrium that makes its competitive clientelism operate relatively smoothly. One reason for India's exception is, paradoxically, its size and diversity, which helps to prevent a ruling coalition from imagining that it can get away with significant administrative interventions in elections. Intervention to benefit a complex ruling coalition of diverse factions is in itself complex and this complexity can help to ensure an informal rule of law emerging for the conduct of elections. A further factor that helps the credibility of elections in India is that it is a large federal country with elections that are organized at the state level. If excessive violations happen within a particular state, the federal government has strong incentives to intervene to prevent a particular state descending into crisis. The federal government can impose the president's rule and re-run the election. Therefore, while irregularities, violence and the use of 'black' money from the informal economy does happen in India, the parties know that an outcome that is significantly out of line with their organizational strength on the ground cannot be sustained. Third-party 'institutional' oversight of electoral outcomes is far less credible in smaller states with competitive clientelism. In such states, electoral crises are more frequent and occasionally lead to military takeovers. An understanding of this political settlement suggests that the problem is unlikely to be solved simply by attempting a stronger enforcement of formal electoral laws. Considerable attention has to be given to strategies that assist the evolution of an informal rule of law for political coalitions, and a shared understanding amongst elites about how this political settlement actually works. For reasons of space we have not discussed another important dimension of the distribution of power between economic and political organizations (Khan, 2010). However, the discussion so far is sufficient to show the importance of focusing on pragmatic governance strategies that aim to overcome particular market failures constraining growth in the context of specific political settlements.

\section{Governance for growth: issues and challenges and the case of Thailand}

Our discussion of Thailand draws on a series of studies of growth-enhancing governance in a number of countries (Khan, 2008b, 2009a, 2009b, 2010). Figure 4 summarizes the phases in the evolution of the political settlement in Thailand from the perspective of the dimensions referred to earlier (the distribution of power between political organizations and the productive capabilities and political connections of economic organizations). Here, we will focus on the important transition from the second to the third phase, when Thailand moved from a period of competitive clientelism in the 1980s and 1990s-a period that is known for its political corruption and 'money politics'-to the phase that the 1997 pro-democracy constitution and the financial crisis ushered in, which paradoxically created the conditions for sustaining a dominant party coalition. Both the constitution and the crisis combined to weaken the political power of capitalist organizations, as well as the political organizations that were linked to them. The result was not the emergence of a rule-following social democracy as the framers of the constitution expected (and we would argue that this is not possible in any developing country) but rather allowed a reconfiguration of existing political organizations into a dominant party (the Thai Rak Thai of Thaksin and its successors). The implications for inclusive growth identify some of the challenges for institution-building and reform in developing countries. On the one hand, Thaksin's politics were more 'inclusive' because he 
succeeded in building a dominant party system that was based on a promise of populist redistributive strategies operating through the formal government budget, which were indeed partially implemented. For instance, the 30-baht healthcare system significantly increased access to virtually free healthcare for the poor. On the other hand, other formal implementation capabilities were weak and contributed to the abandonment of strategies for industrial restructuring after the 1997 crisis. Moreover, Thaksin, unlike his predecessors, did not require the political and economic support of capitalist organizations to survive because his dominant party had an assured electoral constituency based on the promise to tax the middle class and distribute to the poor. This autonomy from the capitalist sector allowed Thaksin to capture unproductive rents in his own business dealings, which had further consequences for investor confidence and capacity building.

\begin{tabular}{|c|c|}
\hline \multicolumn{2}{|c|}{ THAILAND } \\
\hline $\begin{array}{c}\text { CHARACTERISTICS OF POLITICAL } \\
\text { SETTLEMENT }\end{array}$ & $\begin{array}{c}\text { BROAD FEATURES OF INSTITUTIONS } \\
\text { AND GROWTH }\end{array}$ \\
\hline $\begin{array}{c}\text { Vulnerable Authoritarianism with } \\
\text { Weak/Moderate Capability / Politically } \\
\text { Weak Capitalists 1960s-1970s }\end{array}$ & $\begin{array}{c}\text { Capitalist rights supporting rapid } \\
\text { accumulation but with weak industrial } \\
\text { policy institutions }\end{array}$ \\
\hline $\begin{array}{c}\text { Competitive Clientelism with moderate-to- } \\
\text { high capability / powerful capitalists: Mid } \\
\text { 1970s-2001 }\end{array}$ & $\begin{array}{c}\text { Rapid growth supported by factional } \\
\text { capitalist rent-seeking and limited } \\
\text { industrial policy }\end{array}$ \\
\hline $\begin{array}{c}\text { 'Unproductive' Dominant Party with high } \\
\text { capability / politically delinked capitalists: } \\
\text { 2001-2008 }\end{array}$ & $\begin{array}{c}\text { Adverse formal institutions supporting } \\
\text { growth in formal sector but populist } \\
\text { redistribution to the poor. Reliance on } \\
\text { foreign investments grows }\end{array}$ \\
\hline $\begin{array}{c}\text { Backlash: Authoritarianism with a } \\
\text { Democratic Face 2008 }\end{array}$ & Political and policy uncertainty \\
\hline
\end{tabular}

Figure 4: Evolution of the Political Settlement in Thailand

Source: (Khan, 2010).

The pro-democracy constitution in Thailand that was implemented at the turn of the century coincided with a rapid recovery from the 1997 financial crisis. Investments and the growth rate recovered but to a lower level compared with the preceding period (Table 1). However, an abrupt termination of the arrangements that had allowed gradual capability-building within domestic productive organizations also meant that manufacturing growth was now driven by multinational takeovers and investments. The implications were complex, with significant short-term benefits but more serious longer-term constraints on the capacity building required in a middle-income country to progress up the value chain towards a greater emphasis on design and innovation. Thailand appeared to abandon previous strategies of building domestic organizational and entrepreneurial capabilities precisely when more significant domestic capabilities were required to drive growth up the value chain. These paradoxical results were interconnected. Thaksin's power base in the countryside and his strategy of weakening competing political organizations meant that domestic capitalist firms could no longer use formal and informal institutions to support capability 
development. At the same time, the implementation capabilities of his dominant party coalition were too limited to carry out industrial restructuring from above.

Table 1: Thailand: Output and Productivity Growth 1981-2005

\begin{tabular}{|c|c|c|c|c|c|}
\hline GROWTH RATES & $\begin{array}{c}\text { Pre-Boom } \\
1981-86\end{array}$ & $\begin{array}{c}\text { Boom } \\
1987-96\end{array}$ & $\begin{array}{c}\text { Crisis } \\
1997-98\end{array}$ & $\begin{array}{c}\text { Recovery } \\
1999-2002\end{array}$ & $\begin{array}{c}\text { Thaksin } \\
\text { 2000-2005 }\end{array}$ \\
\hline \multicolumn{6}{|l|}{ All Sectors } \\
\hline Output & 5.5 & 9.5 & -5.9 & 4.1 & 5.3 \\
\hline \multicolumn{6}{|l|}{ Factor Contributions } \\
\hline Capital Stock & 3.2 & 4.8 & 1.8 & 1.0 & \\
\hline Labour & 1.4 & 2.7 & 1.3 & 1.9 & \\
\hline Land & 0.03 & 0.01 & 0.01 & 0.01 & \\
\hline TFP & 0.9 & 2.0 & -9.0 & 1.2 & \\
\hline Labour Productivity & 2.6 & 7.6 & -5.8 & 3.4 & \\
\hline \multicolumn{6}{|l|}{ Manufacturing } \\
\hline Output & 5.8 & 13.2 & -4.8 & 7.1 & 6.9 \\
\hline \multicolumn{6}{|l|}{ Factor Contributions } \\
\hline Capital Stock & 4.1 & 7.4 & 3.2 & 1.6 & \\
\hline Labour & 1.5 & 5.1 & 2.7 & 2.3 & \\
\hline$\underline{\text { TFP }}$ & 0.15 & 0.7 & -10.7 & 3.2 & \\
\hline Labour Productivity & 3.1 & 6.0 & -7.7 & 2.4 & \\
\hline $\begin{array}{l}\text { Investment Share } \\
\text { (\% of GDP) }\end{array}$ & 28.3 & 38.4 & 27.1 & 22.8 & 31.8 \\
\hline
\end{tabular}

Source: Calculated from Warr (2005) Tables 1.3 and 1.4, and World Bank (2008).

The political and economic crisis of 1997 was partly due to excessively strong links between businesses and political organizations and this needed to be reformed. These links had allowed politically connected businesses to access rents but sometimes these informal arrangements also indirectly solved important market failures and contributed to the dramatic growth over the previous three decades. Rents allowed learning-by-doing to be financed while the competition between the factions supporting different groups of capitalists ensured that these rents were effectively temporary and created strong incentives for high levels of effort (Khan, 2000b, 2000a). However, as the economy became more sophisticated these arrangements had to change and more effective methods of assisting capability development were necessary. The late 1990s were therefore a period of missed opportunities for growthenhancing governance reforms. Instead, the constitutional changes brought about a change in the political settlement, which allowed the emergence of Thaksin's dominant party. However, this too was unstable because while excluded organizations of capitalists and the middle classes were initially weak, they retained potential support within the army and the monarchy. The backlash that happened in 2006 in the form of a military coup against Thaksin, followed by political uncertainty, will not be discussed further in this paper (see Khan, 2010). Our focus here is to look at a few critical, informal arrangements that worked during the competitive clientelist period, the reasons for their failure and the emergence of a dominant party system and finally 
the missed opportunities of growth-enhancing governance prior to the constitutional crisis that began with the military coup.

When both formal and informal arrangements are involved in allocating resources and creating incentives, rents provide a useful lens through which to examine the role of informal institutions. Both formal and informal institutions can create rents (defined as resource flows that would not exist in the absence of particular institutions). Rents are more visible than informal arrangements, so examining rents can help to identify the implicit informal arrangements that are responsible for the allocation of particular rents and the terms on which they are available. The ways in which formal and informal institutions affect economic incentives and therefore market failures can then be analysed by looking at significant rents and the implicit and explicit rules of their allocation. Figure 5 summarizes some of the most important rents in different periods in Thailand. The first two rows cover the period of competitive clientelism, while the third row refers to the dominant party period after 1997.

Putting these institutional arrangements in the context of the political settlement in Thailand over this period helps to explain the successes and failures of implementation and why the effectiveness of the underlying institutional ensemble was changing over time. Competitive clientelism during the 1980s and 1990s was relatively successful in Thailand because of some specific features of the Thai competitive clientelist political settlement (Doner and Ramsay, 2000; Khan, 2000a: 101-104). Growth accelerated, as Table 1 shows, over the 1980s and 1990s, particularly compared with the virtual zero growth that the country experienced under the free trade imposed by the Bowring Treaty from 1855 to 1950 (Manarungsan, 1989). The competition for rents between competing political organizations was different from the competitive clientelism in many other developing countries because, in Thailand, productive capitalists were politically powerful and more likely to be in leadership positions in political organizations. This was partly due to the fact that Thailand was not colonized and its political organizations grew gradually and in line with the financing capabilities of emerging capitalists, rather than being creations of colonial administrations or anti-colonial movements. Moreover, as Thailand had many such political organizations, no single organization could monopolize power for too long. Political power provided access to temporary rents, but the incentives were to convert these into productive assets or to finance periods of learning by doing, so that economic organizations remained economically viable out of power. Indeed building productive capabilities was a pre-condition for being able to finance political activity when out of power and therefore to have a chance of returning to power (Khan, 2000a: 101-104; Phongpaichit and Baker, 2008: 267-269). 


\begin{tabular}{|c|c|c|}
\hline & & \\
\hline & \multirow{3}{*}{$\begin{array}{l}\text { Competitive Clientelism } \\
\text { ensured access to rents was } \\
\text { relatively competitive because } \\
\text { of competition between } \\
\text { political organizations } \\
\text { controlled by competing } \\
\text { economic organizations. } \\
\\
\text { Competing organizations } \\
\text { could not be permanently } \\
\text { blocked and together with } \\
\text { formal hard budget } \\
\text { constraints, this ensured } \\
\text { competitiveness. A permanent } \\
\text { flow of rents to particular } \\
\text { factions was not feasible. }\end{array}$} & \multirow{3}{*}{$\begin{array}{l}\text { Rapid growth of large } \\
\text { economic organizations } \\
\text { with moderate technology } \\
\text { Dramatic growth (particularly } \\
\text { 1980s) in low and medium- } \\
\text { tech sectors where learning } \\
\text { periods were short. } \\
\text { But competitive clientelism } \\
\text { also damaged autonomy of } \\
\text { critical agencies: by the late } \\
\text { 1980s and 1990s the Bank of } \\
\text { Thailand, the NESDB and } \\
\text { other agencies became } \\
\text { targets of ruling factions. }\end{array}$} \\
\hline $\begin{array}{l}\text { Formal rents based on fiscal } \\
\text { incentives, import and export } \\
\text { controls and licensing. }\end{array}$ & & \\
\hline $\begin{array}{l}\text { n } \\
\text { ns on } \\
\text { ial } \\
\text { sets, } \\
\text { I } \\
\text { sider }\end{array}$ & & \\
\hline & $\begin{array}{l}\text { Technocratic and political } \\
\text { (growth-enhancing) } \\
\text { governance capabilities }\end{array}$ & \multirow{2}{*}{$\begin{array}{l}\text { Upgrading and } \\
\text { diversification through } \\
\text { conditional support } \\
\text { particularly over 1980-97 } \\
\text { Examples include diesel } \\
\text { engines } 1980-85, \text { cathode ray } \\
\text { tubes } 1985 \text { onwards. } \\
\text { But growing politicization of } \\
\text { agencies and cheap capital } \\
\text { imports created adverse } \\
\text { incentives. BOI responded by } \\
\text { supporting firms independent } \\
\text { of nationality by mid-1980s. }\end{array}$} \\
\hline $\begin{array}{l}\text { BOI } \\
\text { id } \\
\text { ident } \\
\text { y }\end{array}$ & $\begin{array}{l}\text { Effective technocratic } \\
\text { capabilities existed in some } \\
\text { agencies and there were } \\
\text { moments of political support } \\
\text { for such strategies even in } \\
\text { overall context of competitive } \\
\text { clientelism. }\end{array}$ & \\
\hline & \multirow{3}{*}{$\begin{array}{l}\text { Thaksin's Dominant Party } \\
\text { wanted to unravel the } \\
\text { competitive clientelist } \\
\text { political settlement. In } \\
\text { addition, regulated by } \\
\text { international agreements } \\
\text { such as WTO and FTAs } \\
\\
\text { Limited attempt at developing } \\
\text { technology policy framework } \\
\text { rapidly abandoned. FTAs and } \\
\text { WTO limit capability of } \\
\text { governments to create } \\
\text { temporary rents. Governance } \\
\text { focus shifts to ensuring } \\
\text { quality of skills. }\end{array}$} & \multirow{3}{*}{$\begin{array}{l}\text { Rapid growth of FDI in } \\
\text { assembly operations with } \\
\text { agglomeration economies } \\
\text { Automotive sector success } \\
\text { story but ownership of } \\
\text { technology and bulk of profits } \\
\text { is foreign. } \\
\text { Challenge of increasing } \\
\text { domestic value added. } \\
\text { Country vulnerable to } \\
\text { relocations of FDI. Political } \\
\text { crisis as dominant party } \\
\text { overthrown and FDI less } \\
\text { confident. }\end{array}$} \\
\hline $\mathrm{ng}$ & & \\
\hline $\begin{array}{l}\text { ally } \\
\text { fiss }\end{array}$ & & \\
\hline
\end{tabular}

Figure 5: Phases of Governance and Growth in Thailand

Source: (Khan, 2008b).

A second, more formal, set of institutional arrangements were also important in Thailand, and failures of adaptation in this area are significant if we want to identify missed opportunities and challenges. Key macro-economic agencies of the state, in particular the central bank, the Bank of Thailand (BOT), were relatively insulated 
from factional politics. Initially at least, these agencies were able to resist patronclient politics from affecting monetary or exchange rate policy. However by the 1980 s, the growing power of political organizations began to undermine the capacity of technocratic agencies to manage macro-economic aggregates. Competitive clientelism had initially been characterized by an implicit deal between technocrats and politicians whereby the technocrats managed the macro-economy and the politicians allocated sectoral and firm-level rents that were by necessity temporary (Christensen and Siamwalla, 1993: 7; Doner and Ramsay, 2000: 171).

By the end of the Prem Tinsulanond government in 1988, these Chinese walls began to be undermined as new, more robust politicians hired and fired technocrats to assert control over the economy in ways that they thought were required (Rock, 2000: 196199). The outcome was not only that serious macro-economic damage could be inadvertently inflicted, but also that ruling factions could attempt to capture much more significant and long-lived rents by using macro-economic management, thereby upsetting both the dynamic incentives for profit-seeking by business clients and also raising the stakes in political competition. An important set of missed opportunities in developing growth-enhancing governance capabilities in Thailand emerged at this stage. In particular in the 1980s during Prem Tinsulanond's quasi-civilian government, economic agencies exercised considerable effort to promote technology acquisition. The country had by then already acquired a diversified base of basic technology industries and needed to upgrade into more value-generating industries where entry was constrained by significant productivity disadvantages. Technocratic agencies, such as the National Economic and Social Development Board (NESDB), the Bank of Thailand and the Finance Ministry, had capabilities that had not yet been undermined by political appointments. Prem's military-backed government had aspects of an authoritarian ruling coalition and was therefore somewhere between the classifications of competitive clientelism and authoritarianism in Figure 3, although still broadly within a competitive clientelist settlement. It had a longer time horizon than competitive clientelism and better implementation capabilities.

As technology upgrading and investments in learning are subject to serious market failures, the institutions that addressed these problems were particularly important. In the 1980s the Board of Investment (BOI) was implementing ambitious technology upgrading strategies. An example was a project with three joint venture firms to introduce the production of diesel engines for agricultural machinery. The policy instruments included targeted import duties to protect domestic markets, reductions of duties for imported raw materials, entry barriers into the sector to protect initial investors, and a four-year target for achieving $80 \%$ local content. The project was monitored throughout and protection was reduced for those firms that failed to meet the local content requirement at the end of the period (Rock, 2000: 189-190). Strategies like these were paying dividends, not only in Thailand but also in India in the 1980s and 1990s, before these countries signed on to WTO restrictions on these strategies (Khan, 2009b). As long as the economic organizations were not so politically connected that they could subvert the conditions attached to this assistance, the economic outcomes were good in a number of projects.

However, by the mid-1980s the conditions for supporting domestic capital in technology acquisition were being weakened. Instead of looking for new instruments for delivering support that could be better enforced within that political settlement, or 
shifting support to different groups or sectors that lacked the power to subvert technology acquisition policies, key technocrats in Thailand began to look for foreign companies to drive technology upgrading. At the same time, exogenous changes in the global financial system following the Plaza Agreement of 1985 made Japanese investors interested in countries like Thailand. Net inflows of FDI almost quintupled from the 1980-85 annual average of 6.1 billion baht to 28 billion in 1988 and 45.7 billion in 1989, mostly driven by a huge increase in Japanese FDI (Phongpaichit and Baker, 1997: Table 5.5). These levels were roughly sustained right through to the crisis of 1997 and beyond, but from the perspective of national capability development and with the great benefit of hindsight, we can say that some vital decisions made by technocrats at this critical juncture had damaging consequences.

The 1997 crisis and the new constitution led to a dramatic change in both the political settlement and in economic policies. The outcome was the victory of the populist Thai Rak Thai Party led by the charismatic businessman Thaksin Shinawatra. The new constitution sought to create a modern political system where strong parties would compete on manifestos. It tried to reduce the weight of clientelist provincial interests by introducing a number of seats to be allocated by party lists. It tried to reduce competitive clientelist lobbying by increasing the power of the Prime Minister over the party-for instance, by stipulating that when ministers resigned, they would lose their parliamentary seat, making them more likely to stay with the party. The Prime Minister could call an election with 45 days notice, but a candidate had to be a member of a party for 90 days to stand for election. This was to reduce the threat of defections. A number of independent bodies were also created to check and balance political representatives. However, the framers of the constitution did not understand that constitutional rules cannot create a Weberian state if the material conditions for such a state do not yet exist. Ironically, the rules weakened lower-level political organizations relative to the party leadership by enough to make a dominant party more viable. The weaker the bargaining power of lower-level organizations, the more likely that the dominant party would be able to satisfy their expectations. The lower the threat of their defections, the more likely that the dominant party could continue to win electoral contests. The result of the constitution was, therefore, in many respects worse for the middle-class framers of the constitution and for many capitalists who initially supported Thaksin's party.

When Thaksin set up the Thai Rak Thai Party in 1998, his agenda was strongly influenced by the crisis. He spoke of the need to protect Thailand's competitiveness, respond to the aggressive behaviour of global competitors and have business attitudes replace bureaucratic ones in the running of the country. This struck a chord with both the middle classes who saw the old bureaucratic polity as a cause of the economic mismanagement for which the whole society was paying a price, as well as the stricken Thai businesses that were looking for support and salvation on a scale that the IMF would not recommend. Unfortunately for Thailand, Thaksin turned out to be less strongly committed to industrial development and technological progress than his initial industrial backers had hoped. Part of the problem was that the internal power structure of the dominant party did not provide enough implementation capacity to overcome the resistance to industrial disciplining. As an intuitive populist politician, Thaksin also recognized that a focus on big business was more difficult to sell in the short term and so his rhetoric turned rapidly to support the small entrepreneur and the farmer, even though the employment-generation possibilities in these sectors were 
limited. A rural uplift programme that was based on debt relief, spending programmes and the 30-baht health plan emerged, without any proper costing of their long-term viability.

On top of the constitutional changes that were assisting the maintenance of a dominant party, Thaksin began to spend unprecedented amounts buying in lowerlevel political organizations and his party promised benefits to the poor on a scale never before seen in Thai politics. The 2001 elections allowed Thaksin's party to combine a new politics of offering redistribution to the poor through the budget, together with old-style faction building. This combination made the party politically unassailable in electoral contests. The fiscal programme of redistribution to the poor was at the expense of limiting access to resources for capitalist firms and the middle class, who were no longer electorally or financially important constituencies for the new party. The relatively quick recovery that was achieved after 1999 through demand expansion also reduced the pressure to implement painful restructuring policies on the productive sector that would weed out lagging firms and provide support to the others. The economic recovery was based on Keynesian spending programmes that were focused on rural spending and did not address the longer-term problems of technology upgrading and the development of new growth sectors. The initial spending was financed by borrowing the vast under-used deposits of banks that had stopped lending. The recovery meant that for a time the budget deficit did not grow and it actually began to shrink as growth picked up.

Thaksin had initially been keen about developmental interventions to enhance the competitiveness and capabilities of Thai business. The American business consultant Michael Porter was paid a hefty fee to identify sectors and policies for Thailand to develop competitive niches. By mid-2002 he had identified five unsurprising sectors: tourism, fashion, food, computer graphics and automobiles. Porter provided general and sometimes contradictory recommendations, such as more openness and an end to 'business connections with government' but also micro-level support for specific sectors and firms. He also recommended a free trade agreement with the US without explaining how this might affect industrial policy interventions. What was missing was a discussion of specific market failures constraining growth and the governance agencies and capabilities that needed to be developed to address these problems.

In the end, the government did not proceed with developmental interventions. The bailouts organized by the Thailand Asset Management Corporation (TAMC) showed why developmental policies would require a reorganization of political arrangements and a significant improvement in the capabilities of specific agencies like the TAMC if they were to be effectively implemented. The TAMC was set up by Thaksin to assist the recovery from the crisis by taking up the bad loans from banks and lending to priority sectors. However, the immediate lending of banks and of the TAMC itself showed the enormous power of factional political organizations within the ruling coalition. The dominant party had brought within it many of the existing political organizations with their links to businesses. Phongpaichit and Baker (2009: 112) provide examples of several big businessmen who received loans and debt forgiveness worth billions of bahts for dubious business ventures when they were clearly not short of money given their lavish spending on buying golf courses and other activities. Clearly, these individuals were connected to powerful organizations that were now part of the new ruling coalition. The competitive temporary rents that 
had allowed growth in the past were in danger of becoming permanent rents for those capitalists who were linked to organizations within the dominant party. While capitalists could no longer drive rent creation for themselves, the dominant party structure allowed any beneficiaries of rents to block disciplining attempts. The paradox was therefore one of greater political inclusion at the expense of some of the formal and informal arrangements that had supported processes of capability building by domestic capitalists.

This was therefore another period of missed opportunities for Thailand. The strong electoral support for a party that was initially committed to capability development could have allowed it to create technology support agencies with a narrow enough remit, and with concerted political support for capability building within these agencies, to make their rent management efforts credible. Technological capability development may have been effective if the assisted sectors and firms were selected to ensure that they were not powerful enough to capture rents without providing any social benefit. Financial instruments could also have been devised that were more difficult to capture. For instance, up-front assistance to meet set-up costs in new technologies, followed by exposing the firms to market competition, could have reduced the attractiveness of participation in such schemes for unproductive rent seekers. The successful experience of catching up in the 1980s in Thailand shows that brief periods of support can create the right incentives and compulsions for high levels of effort in learning-by-doing. Technology support agencies may have attempted to improve their governance capabilities by focusing on support that was time bound, and by focusing on particular sectors of capitalists who were less strongly connected to powerful organizations within the party.

Setting up agencies with a defined and effective remit would undoubtedly require an internal confrontation with vested interests, but it is possible that the political moment would have allowed a victory, or enough of a victory, to address important market failures to a greater extent. All we know is that the attempt was not made. As it turned out, Thaksin's emerging response had two negative aspects. First, his own expropriation strategies involving his close family and friends became open and extensive. Tax evasion, land scams and dodgy public purchase contracts were examples. It could be that the acceleration of unproductive rent appropriation by Thaksin's family and business networks would have happened anyway, but if a developmental strategy that could have generated productive surpluses had been blocked by the power structure within the dominant party, the leadership's subsequent decision to capture rents in unproductive ways also made sense. Secondly, economic nationalism and technology policy were quietly dropped and replaced with a more populist support for the poor, for rural interests and small businesses, combined with a growing openness to foreign capital as a way of sustaining technology-driven growth. This too could have been a reflection of the poor implementation capabilities within the party that it discovered during the TAMC experience, and the failure to develop more targeted governance capabilities that could have credibly driven a domestic technology-driven growth strategy.

Around this time foreign investment increased in Thailand, with significant growth in automobiles and electronics. Foreign capital bought out distressed Thai firms and benefited from the base of skilled workers that had emerged. This brought a period of growth but also growing concerns within Thailand about entrepreneurial and 
technological capabilities. As Ohno (2006) points out, even the two most advanced South-East Asian countries, Malaysia and Thailand, are not close to the stage where domestic producers can develop their own design and production capabilities. Progress up the value chain has been slow because a multinational-led strategy puts countries like Thailand in a catch-22 situation. Local production capabilities will only move up the chain if multinationals move up the value chain in local production, allowing domestic producers to move into the spaces that have been vacated. However, multinationals will only move up if domestic producers can fill the gaps and local capabilities are available for the more difficult production and design processes. But these are unlikely to develop locally at a rapid pace without learningby-doing supported by government policies.

Thaksin's political settlement therefore proved to be particularly problematic for addressing the market failures that are relevant to sustaining inclusive growth. When the attempt to restructure the formal productive sector was abandoned, the dominant party appeared to believe that it could sustain its redistributive requirements by squeezing the middle class and domestic capitalists. It was possible to imagine this was a sustainable strategy because the economy had picked up to some extent on the back of multinational investments. However, the excluded political and economic organizations were not entirely powerless and had strong supporters within the army who feared Thaksin's populism would damage the economy and perhaps even undermine the monarchy. The excluded economic organizations and the middle class struck back in the military coup of 2006. The result was a long drawn-out constitutional crisis from 2006 onwards whose roots lie in the failure to construct a political settlement that incorporates developmental strategies for Thailand's domestic economic organizations. The victory of another incarnation of Thaksin's party in 2011 reopened these challenges for Thai policy-makers.

Our brief discussion of Thailand illustrates the importance of a number of concepts and their interrelationships. An understanding of political settlements, as well as the market failures that need to be addressed to assure employment-generating growth, are at the heart of the challenge. To a large extent, the economic analysis of market failures and the comparison of performances and strategies across countries is a technical exercise, but the design and implementation of formal strategies that have a chance of working in different political settlements inevitably involves political judgements. It is also a question of focusing on a small number of issues that are important and solving feasible problems. Thailand's growth story in the 1980s was one of formal and informal institutions working together in serendipitous ways. Its failure to sustain its capability development strategies after 1997 is a story of technocrats and politicians failing to identify the agencies that needed to be built upon and strengthened. While economic growth remains respectable, Thailand's failure to integrate political inclusion with strategies of capability development for the economic organizations that must underpin sustainable inclusive growth lies at the heart of the challenges facing the nation.

\section{REFERENCES}

Acemoglu, D., S. Johnson and J. A. Robinson (2001), "The Colonial Origins of Comparative Development: An Empirical Investigation", American Economic Review, Vol. 91, No. 5, pp. 1369-1401. 
Acemoglu, D., S. Johnson and J. A. Robinson (2002), "Reversal of Fortune: Geography and Institutions in the Making of the Modern World Income Distribution", The Quarterly Journal of Economics, Vol. 117, No. 4, pp. 1231-1294.

Amsden, A. (1989), Asia's Next Giant: South Korea and Late Industrialization, Oxford University Press, Oxford.

Aoki, M., H.-K. Kim and M. Okuno-Fujiwara (eds.) (1997), The Role of Government in East Asian Economic Development: Comparative Institutional Analysis, Clarendon Press, Oxford.

Arndt, C. and C. Oman (2006), Uses and Abuses of Governance Indicators, Development Centre of the Organisation for Economic Co-Operation and Development (OECD), OECD, Paris.

Christensen, S. R. and A. Siamwalla (1993), Beyond Patronage: Tasks for the Thai State, Thailand Development Research Institute, Bangkok.

Clark, G. and S. Wolcott (2002), One Polity, Many Countries: Economic Growth in India, 1873-2000, in D. Rodrik (ed.) Institutions, Integration, and Geography: In Search of the Deep Determinants of Economic Growth, Princeton University Press, Princeton NJ. Available HTTP: $<\underline{\text { http://ksghome.harvard.edu/ .drodrik.academic.ksg/Growth\%20volume/Clark- }}$ India.pdf $>$

Commission on Growth and Development (2008), The Growth Report: Strategies for Sustained Growth and Inclusive Development, Conference Edition, World Bank, Washinton DC.

Doner, R. F. and A. Ramsay (2000), Rent-seeking and Economic Development in Thailand, in M. H. Khan and K. S. Jomo (eds.) Rents, Rent-Seeking and Economic Development: Theory and Evidence in Asia, Cambridge University Press, Cambridge.

Glaeser, E. L., R. La Porta, F. Lopez-de-Silanes and A. Shleifer (2004), "Do Institutions Cause Growth?", Journal of Economic Growth, Vol. 9, No. 3, pp. 271303.

Kaufmann, D., A. Kraay and M. Mastruzzi (2007), "Growth and Governance: A Reply", The Journal of Politics, Vol. 69, No. 2, pp. 555-562.

Khan, M. H. (1999), The Political Economy of Industrial Policy in Pakistan 19471971. SOAS Department of Economics Working Paper No. 98, School of Oriental and African Studies, University of London.

Khan, M. H. (2000a), Rent-seeking as Process, in M. H. Khan and K. S. Jomo (eds) Rents, Rent-Seeking and Economic Development: Theory and Evidence in Asia, Cambridge University Press, Cambridge. 
Khan, M. H. (2000b), Rents, Efficiency and Growth, in M. H. Khan and K. S. Jomo (eds.) Rents, Rent-Seeking and Economic Development: Theory and Evidence in Asia, Cambridge University Press, Cambridge.

Khan, M. H. (2007a), Governance and Growth: A Preliminary Report, Research Paper supported by DFID grant. SOAS, London. Available HTTP: $<$ http://mercury.soas.ac.uk/users/mk17/Docs/Preliminary\%20Report.pdf $>$

Khan, M. H. (2007b), Governance, Economic Growth and Development since the 1960s, in J. A. Ocampo, K. S. Jomo and R. Vos (eds.) Growth Divergences: Explaining Differences in Economic Performance, Orient Longman, Zed Books and Third World Network, Hyderabad, London and Penang. Available HTTP: $<$ http://www.un.org/esa/desa/papers/2007/wp54_2007.pdf $>$

Khan, M. H. (2008a), Governance and Development: The Perspective of GrowthEnhancing Governance, in GRIPS Development Forum (ed.) Diversity and Complementarity in Development Aid: East Asian Lessons for African Growth, National Graduate Institute for Policy Studies, Tokyo. Available HTTP: $<$ http://mercury.soas.ac.uk/users/mk17/Docs/GRIPS.pdf $>$

Khan, M. H. (2008b), Vulnerabilities in Market-Led Growth Strategies and Challenges for Governance, Research Paper Series on Governance for Growth, School of Oriental and African Studies, University of London, London. Available HTTP:

$<$ http://mercury.soas.ac.uk/users/mk17/Docs/Vulnerabilities\%20in\%20Market\%20Le d\%20Growth $\% 20$ Strategies $\% 202$. doc $>$

Khan, M. H. (2009a), Governance Capabilities and the Property Rights Transition in Developing Countries, Research Paper Series on Governance for Growth, School of Oriental and African Studies, University of London, London. Available HTTP: $<$ http://mercury.soas.ac.uk/users/mk17/Docs/Property\%20Transitions\%20internet.pdf $>$

Khan, M. H. (2009b), Learning, Technology Acquisition and Governance Challenges in Developing Countries, Research Paper Series on Governance for Growth, School of Oriental and African Studies, University of London, London. Available HTTP: $<$ http://mercury.soas.ac.uk/users/mk17/Docs/Learning\%20and\%20Technology $\% 20 \mathrm{~A}$ cquisition $\% 20$ internet.pdf $>$

Khan, M. H. (2010), Political Settlements and the Governance of Growth-Enhancing Institutions, Research Paper Series on Governance for Growth, School of Oriental and African Studies, University of London, London. Available HTTP: $<\underline{\text { http://mercury.soas.ac.uk/users/mk17/Docs/Political\%20Settlements\%20internet.pdf }}$ $>$

Kurtz, M. J. and A. Schrank (2007), "Growth and Governance: Models, Measures and Mechanisms", The Journal of Politics, Vol. 69, No. 2, pp. 538-554.

Lall, S. (1992), "Technological Capabilities and Industrialization", World Development, Vol. 20, No. 2, pp. 165-186. 
Lall, S. (2000a), Selective Industrial and Trade Policies in Developing Countries: Theoretical and Empirical Issues, Working Paper Series No. 48, Queen Elizabeth House, Oxford.

Lall, S. (2000b), Skills, Competitiveness and Policy in Developing Countries, Working Paper Series No. 46, Queen Elizabeth House, Oxford.

Lall, S. and M. Teubal (1998), "“Market-Stimulating" Technology Policies in Developing Countries: a Framework with Examples from East Asia", World Development, Vol. 26, No. 8, pp. 1369-1385.

Manarungsan, S. (1989), Economic Development of Thailand 1850-1950: Responses to Challenges of the World Economy, PhD dissertation, Groningen University, Groningen.

Nelson, R. R. and S. G. Winter (1982), An Evolutionary Theory of Economic Change, Belknap Press of Harvard University Press, Cambridge Mass.

North, D. C. (1990), Institutions, Institutional Change and Economic Performance, Cambridge University Press, Cambridge.

North, D. C., J. J. Wallis, S. B. Webb and B. R. Weingast (2007), Limited Access Orders in the Developing World: A New Approach to the Problem of Development, World Bank Policy Research Paper No. 4359, World Bank, Washington DC.

North, D. C., J. J. Wallis and B. R. Weingast (2009), Violence and Social Orders: A Conceptual Framework for Interpreting Recorded Human History, Cambridge University Press, Cambridge.

Ohno, K. (2006), Vietnam's Industrial Policy Formulation: To Become a Reliable Partner in Integral Manufacturing, in K. Ohno and T. Fujimoto (eds.) Industrialization of Developing Countries: Analyses by Japanese Economists, National Graduate Institute for Policy Studies, Tokyo.

Phongpaichit, P. and C. Baker (1997), Thailand: Economy and Politics, Oxford University Press and Asia Books, Oxford and Bangkok.

Phongpaichit, P. and C. Baker (2009), Thaksin. Second ed., Silkworm Books, Chiang Mai.

Phongpaichit, P. and C. Baker (eds.) (2008), Thai Capital after the 1997 Crisis, Silkworm Books, Bangkok.

Rock, M. T. (2000), Thailand's Old Bureaucratic Polity and its New SemiDemocracy, in M. H. Khan and K. S. Jomo (eds.) Rents, Rent-Seeking and Economic Development: Theory and Evidence in Asia, Cambridge University Press, Cambridge. 
Stiglitz, J. E. (1987), Learning to Learn, Localized Learning and Technological Progress, in P. Dasgupta and P. Stoneman (eds.) Economic Policy and Technological Development, Cambridge University Press, Cambridge.

Wade, R. (1990), Governing the Market: Economic Theory and the Role of Government in East Asian Industrialization, Princeton University Press, Princeton.

Warr, P. (2005), Boom, Bust and Beyond, in P. Warr (ed.) Thailand: Beyond the Crisis, Routledge and Curzon, London.

World Bank (1993), The East Asian Miracle: Economic Growth and Public Policy, Oxford University Press, Oxford.

World Bank (2008), World Development Indicators Online, Accessed through Economic and Social Data Service. ESDS, Manchester. 